\title{
ABRAHAM FLEXNER AS CRITIC OF BRITISH AND CONTINENTAL MEDICAL EDUCATION
}

\author{
by \\ THOMAS NEVILLE BONNER *
}

\begin{abstract}
When Abraham Flexner landed in England in October 1910, he was already well known in British medical circles. His report on medical education in the United States and Canada, published earlier in the year, had been widely distributed in Europe by Nicholas Murray Butler, an influential trustee of the Carnegie Foundation for the Advancement of Teaching. When Flexner called on the president of the Royal College of Surgeons, Henry Butlin, on 8 October, Butlin told him of the impact his American study had made in Britain. "You didn't need any letter of introduction from Osler," Flexner recounted the conversation, "I've read your report, it's masterly. I am preparing a memorial to the Royal Commission on London University and you are my authority - see here, here's your Report . . . every margin filled with pencil comments showing how you have analyzed our difficulties for us ...". 1
\end{abstract}

Flexner's arrival in Britain was timely. Medical education throughout the island was in turmoil. Dissatisfaction with the variety of routes to licensure, the wide differences between Scottish and London requirements for degrees, and the rigidity of the seniority system within the hospitals had been growing since the 1880 s. In addition, new concerns over British backwardness in laboratory study and scientific research were creating a sense of crisis in those aware of developments in Germany and America. ${ }^{2}$ William Osler himself, who had arrived at Oxford to fill the Regius Chair in 1905, had sharply criticized a year earlier the neglect of laboratory studies in British medical schools in a widely reported address at the London Hospital. ${ }^{3}$

Flexner conferred with Osler and other members of the British medical establishment on his arrival in Britain. He carried a letter from Henry Pritchett, his chief at the Carnegie Foundation, to Sir William McCormick, who was then in charge of Carnegie philanthropies in Scotland. It was through McCormick, a member of the recently established Royal Commission on University Education in London, that he met Lord Haldane, Chairman of the Commission, and learned that

\footnotetext{
*Thomas Neville Bonner, Department of History, Wayne State University, Detroit MI 48202, USA.

${ }^{1}$ Abraham Flexner to wife, 8 October 1910. This and all other references to Flexner's correspondence are from the Flexner Papers in the Library of Congress, Washington, DC.

2 George Haines IV, Essays on German influence upon English education and science, 1850-1919, Hamden, Connecticut, Archon Books, 1969, pp. 151-2. See, too, Peter Alster, The reluctant patron: science and the state in Britain, 1850-1920, Oxford, Berg, 1987.

${ }^{3}$ Harvey Cushing, The life of Sir William Osler, London, Oxford University Press, 1940, p. 876.
} 
Haldane had not been planning to include the medical schools in his study. ${ }^{4}$ But Flexner's report and presence in Europe to study European medical schools had stirred up interest in medical education within the Commission itself. "I learned, greatly to my surprise," Flexner wrote to Pritchett, "that a copy of the Report is in the hands of every member of the Royal Commission ... . They are ready to attack the problem of organizing a teaching medical department on modern lines." 5 Flexner himself was invited to appear before the Commission and give his views on British medical education. He spent a week-end with the Oslers at Oxford and showed him the draft of a statement he proposed to submit. "I feared it might be regarded as too direct," he told Pritchett, but Osler "approved it unqualifiedly", arguing "that only by thus making a sharp issue, will the Commission be assisted." Osler arranged for Flexner to meet Sir Robert Morant, the Permanent Under Secretary of the Board of Education and also a member of the Royal Commission. Morant, too, urged Flexner to state the issue baldly "so that the fight may go to the merits of the question". Morant told him that Osler himself would testify later and Flexner suggested that American experts such as Pritchett and William Henry Welch be asked for written statements and that Friedrich von Müller, the noted German internist, be brought from Munich. The proposal to organize medical teaching in London on University lines, Flexner wrote to Pritchett, "is entirely novel and unexpected by the local profession; so that a huge howl is inevitable." 6

Flexner's statement before the Commission became the point of departure for the rest of the hearings on medical education. He spoke with the same frankness that had marked his work on American medical schools. "Medical education in London", he told Lord Haldane and the other commissioners, "is not fully modern . . . even the fundamental branches are not as yet entirely emancipated or fully developed. Anatomy is still here and there in the hands of practising surgeons; pharmacology is found in only one school. These backward conditions are . . . due chiefly to poverty and dispersion." Nowhere did he see evidence that the British had learned the concept of the clinician as primarily a teacher. "It is still supposed", he said, "that because a man is an accomplished physician he is an excellent teacher. Clinical teaching in London remains an incident in the life of a busy consultant." Nor did he find anywhere the close interaction between the fundamental sciences and the medical clinics he admired in Germany. The British system simply did not promote scientific study or teaching. Medical education in London, he concluded, was "not an organic whole: it falls into two more or less unsympathetic parts." What London and Great Britain needed, he told the Commission, was a university model that would "break the existing level of mediocrity". That would mean reconstituting the teaching staff, breaking up the existing seniority system in appointments, and providing adequate salaries to medical professors so that they could devote all of their time to teaching and investigation. Asked by Lord Haldane whether the ideal model could be found in Baltimore, Flexner replied simply, "yes". For all his strictures against conditions in Britain, however,

\footnotetext{
${ }^{4}$ Abraham Flexner, I remember, New York, Simon and Schuster, 1940, pp. 139-41. See, too, Negley Harte, The University of London 1836-1986, London, Athlone Press, 1986, pp. 182-94.

${ }^{5}$ Flexner to Pritchett, 21 October 1910.

${ }^{6}$ Flexner to Pritchett, 9 November 1910.
} 
Flexner described them as "much more favorable here from the point of the undergraduate student than anywhere on the continent" and "the clinical training is immensely better than it is in the ordinary Medical School in America."

Flexner's plan of creating university professorships with responsibility for clinical teaching in the hospital schools of London was vigorously supported by William Osler, who urged the establishment of "hospital units" in the London hospitals similar to those in Germany and Baltimore. "In the very best hospitals," Osler told the commissioners,

the arrangements are on old and very unsatisfactory lines. In long, uphill years the ambitious young man goes through the position of resident physician, medical registrar, assistant physician, and at $\mathbf{4 0}$ (if he is lucky) gets wards. Then a visit two or three times in the week with a house physician, a certain amount of teaching, and possibly some laboratory work, but he has a living to get, and practice becomes the first consideration .... The problem is how to place a dozen or more teachers in every Medical School in the same relation with the University as the Professors of Physiology and of Physics - how to give to each of them a department organized on university lines ....8

But much of the testimony before the Haldane Commission, as Flexner had predicted, was in strong opposition to the German-Hopkins university model championed by Flexner and Osler. The former president of the Royal College of Surgeons, Sir Henry Morris, warned that in Britain 'the 'Professor' is not so universally looked upon as the highest principle of intellectual ambition or social glory .... German training is very theoretical and scientific and not a preparation fitting a man to go at once into practice." He objected to the "crispness, dogmatism, and ... cocksureness" of Flexner's testimony. "I am not aware", said Morris acerbically, "that Mr. Abraham Flexner is either a clinician or a science teacher." A number of witnesses objected to the "Oslerian unit" in the hospitals, as Morris termed it, as lacking the value of clinical demonstrations by practising physicians and inflicting a hardship on hospital patients. Morris called it "only the old German plan under a modern American name". ${ }^{9}$ And almost all those testifying urged the Commission not to sacrifice the great strength of the existing English system of clerks and dressers, which the Dean of the London School of Medicine for Women called "the soul of the English system of training medical students". Flexner wrote to Pritchett after his testimony that the Commission's main difficulty "lies not only in grasping the main idea, but in pushing it thro', over the certain hostility of the local profession. The doctors here for years systematically diffused the idea that as 'practical' schools those of London are the best in the world and some questions asked seemed to imply a fear that any improvement on scientific lines would impair their "practical' value."10

In its report, the Haldane Commission largely endorsed Flexner's recommendations, while emphasizing the importance of retaining the clerkship system under professorial direction. "The main features of the [report]", said Haldane in 1913, "are a recognition

\footnotetext{
${ }^{7}$ Royal Commission on University Education in London, Reports, 5 vols., London, HMSO, 1910-12, vol. 3, pp. 2, 6 .

${ }^{8}$ Royal Commission on University Education in London, Final Report of the Commissioners, London, HMSO, 1913, p. 109.

${ }^{9}$ Reports, op. cit., note 7 above, vol. 5, pp. 21-5.

${ }^{10}$ Flexner to Pritchett, 13 November 1910.
} 
of the great strides being made in university education by the United States and Germany." 11 The Commission urged the creation of medical and surgical units within the hospitals under the care of professors at the University of London. "The standard of the teachers in these subjects", said the report, "ought not to be different from that of University Professors in other subjects and it is therefore necessary to appoint and pay professors of the various branches of clinical medicine and surgery who will devote the greater part of their time to teaching and research."12 Flexner was pleased with the outcome. "No more incisive document on the subject", he said later of the report, "has ever been written." His friendships with Haldane, Morant, and McCormick became some of the closest associations of his life. His views on British medical education were cited frequently in the years to come. "May I say how pleased I was," wrote Carey Thomas, the influential president of Bryn Mawr College, in 1913, "to see the recognition which your [report] received in England in the Blue Book on the reorganization of the University of London. It is the first time I remember an American report or usage influencing English education in this direct way."13 Because of the World War in 1914 and its sequel, nothing was done for some years to implement the Haldane recommendations. Gradually, however, beginning in the 1920s, the University of London was able to assert greater control over the clinical teaching in London's hospital schools, a process that was not completed until after World War II. ${ }^{14}$

Flexner travelled to Europe to study medical education in Britain and on the Continent. The purpose of the Carnegie-sponsored study, he wrote to Pritchett, following his appearance before the Haldane Commission, was "not to see and to describe excellent institutions at various points, but to look at and to describe the medical education of several countries taken as a whole, in order to see how they have solved their problems and what relations the entire system of education bears to university, and particularly to medical training." 15 On the Continent, he found that his American report was as well known in some places as in Britain. Nicholas Murray Butler, according to a letter from Pritchett, "has just come home and he is most profuse in his praise of the estimation in which your report is held in Berlin."16 In Munich, Friedrich von Müller told Flexner that the medical school had received a note from the Reichschancellor in Berlin "requesting that all doors be opened unto me". ${ }^{17}$ His itinerary in Europe was full and rivalled his whirlwind visits to American medical schools. In late November, 1910, for example, he wrote to his wife that "I may succeed in doing Köln and Düsseldorf in one day for they are close together and I have little to do in either; in that case I may do Marburg instead of Frankfurt, say Friday and Saturday."18

${ }^{11}$ Nature, 1913-14, 92: 270-1.

12 Final report, op. cit., note 8 above, p. 121.

${ }^{13}$ M. Carey Thomas to Flexner, 26 September 1913.

${ }^{14}$ Charles Newman, The evolution of medical education in the nineteenth century, London, Oxford University Press, 1957, p. 276. See, too, the two reports by George Newman: Some notes on medical education in England, London, HMSO, 1918, and Recent advances in medical education in England, London, HMSO, 1923.

${ }^{15}$ Flexner to Pritchett, 22 November 1910.

${ }^{16}$ Pritchett to Flexner, 27 October 1910.

${ }^{17}$ Flexner to wife, 18 July 1910.

${ }^{18}$ Flexner to wife, 27 November 1910. 
The resulting study, published in time to be considered by the Haldane Commission, attributed the continuing superiority of German medical study to the contiguity of the sciences and the medical clinics within every German university. In Britain and France, by contrast, "a consistently organized and motivated university school of medicine [still] does not exist."19 But he also saw weaknesses now in the German medical school, particularly in the overloaded curriculum and the overemphasis on the didactic lecture and the class demonstration. "Pedagogically considered," he wrote in 1912, "the German practice is surely mistaken ... . The most brilliant demonstration is . . less educative than a more or less bungled experiment executed by the student with his own hands." ${ }^{20}$ The real strength of the British and French systems, on the other hand, lay in their clinical teaching in the hospitals where pregraduate clerks in Britain or externes in France had "free contact with the actual manifestations of disease". ${ }^{21}$ In a letter to Pritchett written soon after his arrival in Vienna from England in 1910, he said: "I could hardly have planned a more traumatic contrast .... For, on the side of teaching method, the English organization has undoubtedly much to suggest to the Germans as well as to ourselves; while the scientific and clinical ability here [in Vienna] makes the English hospital look absolutely dead. The close juxtaposition of the two experiences", he concluded, "suggests that they are probably complementary rather than contradictory." 22 Without question, it was this "close juxtaposition" of German science and British clinical training that Flexner saw as the great strength of the emerging American model of medical education.

By 1914, Flexner's work and influence on medical education were nearly as well known in Europe as in America. More than 40,000 copies of the two Carnegie reports on medical education were distributed across America, Britain, and the Continent. ${ }^{23} \mathrm{~A}$ flood of editorials in medical and popular journals-135 of them in response to the European report alone-appeared across western Europe and the United States. ${ }^{24}$ Leaders of medical schools, heads of universities, and medical spokesmen read and digested the details of the lengthy academic studies. His files contain numerous letters from influential leaders in medicine and education on both sides of the Atlantic. Behind some of the interest, of course, lay the hope of Carnegie or later Rockefeller gold, but only a tiny handful of Flexner's correspondents ever expected themselves to receive largesse from the foundations for which he worked. His ideas were taken seriously and his counsel was widely sought. As Timothy Jacobson has recently written, Flexner was "a serious intellectual to whom knowledge and thought mattered". 25 The heart of his ideas about medicine lay in his belief that an all-conquering science had made the union between science and medicine both inevitable and irreversible. Inductive teaching of science and medicine was the

\footnotetext{
${ }^{19}$ Abraham Flexner, Medical education in Europe, New York, Carnegie Foundation for the Advancement of Teaching, Bulletin No. 6, 1912, p. 15.

20 Ibid., p. 84.

21 Ibid., p. 202.

22 Flexner to Pritchett, 22 November 1910.

${ }^{23}$ Howard J. Savage to Flexner, 18 July 1924.

24 Clyde Furst to Flexner, 19 July 1912.

25 Timothy Jacobson, Making medical doctors: science and medicine at Vanderbilt since Flexner, Tuscaloosa, University of Alabama Press, 1987, p. 23.
} 


\section{Abraham Flexner as critic}

watchword in a pedagogical revolution that was sweeping over the medical schools. The fledgling physician must himself see, feel, hear, test in the laboratory as well as in the clinic and at the bedside. Only in a lniversity that fused investigative science with practical training could a modern physician be educated. As he wrote in his American report, "The student no longer merely watches, listens, memorizes; he does. His own activities in the laboratory and in the clinic are the main factors in his instruction and discipline." 26 Only a physician thus educated, he believed strongly, could bring effective relief to the suffering of humanity. There could not be two types of medical schools, he argued, one for medical scientists and one for ordinary practitioners, if the aim of medical education was the production of "alert, systematic, thorough, critically open-minded" doctors. ${ }^{27}$ Medicine as science could not be separated from medicine as useful human service. ${ }^{28}$

The power of Flexner's language, buttressed by the revolutionary changes in American medicine and the millions given by the Rockefeller Foundation, affected several generations of medical educators on both sides of the Atlantic. He never wavered in his admiration for German medicine and its adaptation to American conditions by the founders of the Johns Hopkins University School of Medicine. In a major article in the Atlantic Monthly, on the eve of the First World War, he paid tribute to the long leadership held by Germany in educating physicians and chided American "medical Jingoes" who refused to admit the reasons for German superiority. "The Harvard graduate", he wrote, "does not go to Johns Hopkins for larger fields of study; the Johns Hopkins man does not go to Columbia; the Columbia man does not go to Pennsylvania. They all go to Germany, if they can." And what was it they found in Germany that was not available at home? The German system, he argued, assured a "high minimum level" of equipment and organization, a solid preparation before entering the university, total freedom for the student to succeed or fail, unparalleled scientific laboratories, and a clinical faculty that, unlike Britain or America, made careers out of teaching rather than practice. ${ }^{29}$ Although the war diminished Flexner's enthusiasm for German science and medicine, it did not extinguish it. "The plight of the sciences in Germany", he wrote his wife in early 1922, "is deplorable. The whole university edifice is being disintegrated through poverty. If the work of destruction is not halted, the finest intellectual organ ever created will be lost to civilization. For, fresh from France and England, I am struck, as never before, with the superiority of the German University as an engine of scientific progress."30

By this time, he had begun work on a third major study of medical education in Europe and America. Published in 1925, it compared the major Western systems of educating physicians in respect to general education, curriculum, laboratory experience, and clinical training. He divided the historical origins of medical schools into three basic types: the practical, clinical type, native to France and England, that

\footnotetext{
${ }^{26}$ Abraham Flexner, Medical education in the United States and Canada, New York, Carnegie Foundation for the Advancement of Teaching, Bulletin No. 4, 1910, p. 53.

27 Ibid., p. 56.

${ }^{28}$ See the discussion in Jacobson, op. cit., note 25 above, p. 50.

29 Abraham Flexner, 'The German side of medical education', Atlantic Monthly, 1913, 112: 655-60.

${ }^{30}$ Flexner to wife, 28 March 1922.
} 


\section{Thomas Neville Bonner}

had grown out of the hospital; the university type developed in Germany, Scandinavia, Holland, and the German-speaking areas of Switzerland, that owed much to the German university's fusion of scientific research with classroom teaching; and the discredited proprietary type that grew out of America's need for doctors in advance of facilities for training them. ${ }^{31}$ In France, the student was sent immediately into the wards on beginning medical study, and clinical subjects continued to dominate the curriculum; in Britain, the stress was likewise on the practical and the useful with students spending two full years or more on clinical subjects; but in Germany more emphasis was placed on the medical sciences and a review of basic science generally, while the student was given greater responsibility in choosing his own curriculum. Flexner clearly favoured the university context for educating physicians over the clinical-type school he found in France and earlier in Britain. "The medical faculty of Paris, Nancy, or Lyons," he wrote, "was and is, in the first instance, a group of practicing physicians and surgeons, engaged in training apprentices. Their position as university professors does not require that they differ in training, activities, or aims from the teachers of medicine in mere hospital schools." ${ }^{32}$ Throughout, he repeated his old theme of the central role of inductive teaching in medical learning. "Active participation - doing things-is . . . the fundamental note of medical teaching." But the student needed also to see data in relationship to general laws or principles. "The teacher has thus two tasks - to train the student to perceive and to train him, further, to generalize. If the student is told too much at the start, he learns generalizations passively or prematurely ...; whereas, if he does not get beyond the scope of his own senses, his education ... will be deficient in depth and comprehensiveness." 33

He contrasted his latest findings with his earlier reports on European and American medical education in a speech to the Council on Medical Education of the American Medical Association in 1924. British medical education, he reported, showed "new signs of vitality". Modern instruction in anatomy, he told the Council, had been introduced at University College London, while plans for "a broadly conceived school of pathology" had been set in motion at Cambridge. With the help of the Rockefeller Foundation, the English government was now supporting clinical units in several of the London medical schools, as recommended by the Haldane Commission, and the heads of these units were recognized as professors of medicine and surgery in the University of London. ${ }^{34}$ "For the first time," in Flexner's words, "professional full-time teachers of medicine and surgery have been established ...". In France, by contrast, he found medical training "quite stationary" except for Strasbourg, acquired from the Germans, which "gives the country for the first time a modern medical school plant." Strasbourg was "a national experiment station which might endeavour to combine the practical features of French clinical training with the laboratory features and investigative activities characteristic of the German university organization." $\mathrm{He}$

\footnotetext{
31 Abraham Flexner, Medical education: a comparative study, New York, Macmillan, 1925, pp. 19-58.

32 Ibid., p. 20.

33 Ibid., pp. 178-9.

${ }^{34}$ For a discussion of Rockefeller Foundation support for medical education in Britain, see Donald Fisher, 'The Rockefeller Foundation and the development of scientific medicine in Great Britain', Minerva, 1978, 16: $20-41$.
} 
was still critical in 1924 of what he called "the premature and excessive emphasis on the clinic" in France, as well as "the excessively practical character of medical education in Great Britain". The schools of Germany and Austria-"the countries which prior to the war easily led the world in the field of medical education and research"-had suffered mightily from the war but there were signs that they might yet recover their former eminence. In the case of the United States, he told the AMA Council, progress "has been enormously greater than anywhere else". The number of medical schools-150 in 1910-had been cut in half; matriculation requirements had everywhere risen; and the laboratory subjects were almost universally taught by full-time and specially trained teachers. Only in clinical training had movement been slow. ${ }^{35}$

Flexner's work on behalf of medical education reform came to an end when he left the Rockefeller Foundation in 1928. He continued to lecture and write on the subject but his power and influence gradually waned. He stayed in touch with many of his old medical friends and stingingly criticized in private the direction that Rockefeller philanthropies took after his departure. His still enormous energies were thrown into the organization and presidency of the Institute for Advanced Study at Princeton in the 1930s. He spent the last twenty years of his life until 1959 in retirement, carrying on an immense correspondence and busying himself with new interests, including the study of history in his eighties under the tutelage of Allan Nevins.

It has been fashionable in recent years to attack Flexner's educational ideas and to minimize his influence on modern medical education. Some have reduced his role in the education of physicians to that of a latter-day propagandist or muck-raker of ideas set in motion long before 1910 . Others have charged him with responsibility through his reports and philanthropy of forcing medical training into too narrow a channel by seeking to make a medical scientist of every practitioner. One historian has called him a "prize academic snob" for his inflexible insistence on high educational standards. Certainly he came on the educational scene long after William Henry Welch, Franklin P. Mall, John Shaw Billings, and others had transformed American thinking about medical learning. Certainly he was strongly opinionated, often difficult and abrasive personally, and much of his influence came only from his role at the foundations. But he was extraordinarily bright, motivated by a high idealism about science, optimistic about medicine's future, and impatient for change. He played a powerful role in changing ideas and institutions on both sides of the Atlantic. He was a man of considerable breadth of mind, keenly interested in ideas, and was a careful student of the historical evolution of medical schools. His comparative writings on European and American medical education in the crucial years of the late nineteenth and early twentieth century have no parallel before or since; they remain a primary source for turn-of-the-century Western medicine. In light of this larger perspective, it is perhaps time to think more favourably of Flexner's work and achievements in medical education.

${ }^{35}$ Abraham Flexner, 'Medical education, 1909-1924', Educational Record, 1924, pp. 3-17. 